\title{
Inquietações euclidianas
}

\author{
Regina Simplício Carvalho ${ }^{1}$; Silvana Marchesani ${ }^{2}$
}

Nesse período de pandemia, resolvi retomar o encontro com Euclides da Cunha através da leitura do livro Os Sertões. À medida em que me embrenhava pela história, comecei a me indagar, como um autor jovem, na época ele era, conseguiu escrever um livro com tamanha densidade? Que formação ele teve? Onde, como e quando?

Nessa empreitada, fiz o convite à minha colega, amante inveterada da literatura brasileira, a fim de investigarmos a biografia do Euclides e ir além da tragicidade de sua vida, buscando a sua formação.

José Veríssimo já dizia: “O livro (...) do Sr. Euclides da Cunha, é ao mesmo tempo o livro de um homem de ciência (...); de um homem de pensamento (...) e de um homem de sentimento, um poeta, um romancista, um artista".

Euclides nasceu em 1866, na cidade de Cantagalo, na região serrana do estado do Rio de Janeiro. Tendo ficado órfão em tenra idade, foi criado pelos tios. Residiu em Teresópolis, São Paulo, Salvador e na capital Rio de Janeiro. Nesta última, estudou no externato Aquino nos anos 1883 e 1884 a fim de se preparar para a academia militar.

A matriz curricular do externato compreendia desde latim, filosofia retórica e poética até álgebra e desenho topográfico.

Ainda, como colegial, inicia suas publicações no periódico da escola, nominado $O$ democrata, era uma época de efervescência política com o afloramento das ideias republicanas e o fim da monarquia. Nessa ocasião conheceu Benjamin Constant, um dos representantes do positivismo no Brasil, no entanto, apesar de expressa admiração pelo seu mestre e a crença na meritocracia, Euclides não se filiou aos ideais positivistas.

Euclides, depois de uma curta passagem pela escola Politécnica, ingressa-se na Escola Militar. Esta escola formava engenheiros particularmente para servirem ao governo para construção e manutenção da infraestrutura. Os engenheiros formados tinham acento imediato na Estrada de Ferro Central do Brasil.

Em 1897, foi convidado pelo Jornal Província (atual Estado de São Paulo) para cobrir a Campanha de Canudos, a fim de investigar a nominada revolta contra a República, e assim, então,

\footnotetext{
${ }^{1}$ Professora do Departamento de Química/UFV. E-mail: resicar@ufv.br

${ }^{2}$ Professora do Colégio de Aplicação-COLUNI/ UFV. E-mail: marchesani@ufv.br
} 
com 31 anos, desvela a realidade sertaneja e inicia a escrita do seu livro. Ao retornar do sertão, reassume seu posto de engenheiro e continua a escrita do livro concomitante com os seus afazeres até a publicação do mesmo em 1902.

Alguns críticos consideram que Euclides estava afinado com as teorias do evolucionismo, sendo engenheiro, sua obra apresenta traços de cientificismo, bem como de darwinismo e traz também o pensamento de Stuart Mill e Gumplowicz.

O jovem Euclides ousou desvendar a história de Canudos, como bom jornalista, adotou o espírito questionador, fez prevalecer sua consciência crítica e divergiu de suas próprias crenças a fim de compreender as inconsistências da Revolta de Canudos.

A obra é considerada, no contexto literário nacional, o primeiro "livro-reportagem", no período literário conhecido como Pré-Modernismo. A narrativa de Euclides da Cunha, influenciado também pelo determinismo, descreve os acontecimentos como produtos do meio, da raça e do contexto histórico.

A narrativa de Euclides da Cunha destaca-se pela abordagem geográfica, histórica, sociológica e, principalmente, humana do sertanejo: nas palavras do escritor, "o sertanejo é, antes de tudo, um forte". Os nordestinos esperançavam por uma solução que os salvassem, principalmente, de suas condições miseráveis de vida e do pouco ou nenhum auxílio por parte dos governantes. É nesse cenário que Antônio Conselheiro, em Canudos - Bahia, torna-se um líder, aparentemente, religioso dessa gente sofrida e arrasta muitos seguidores para uma luta sem precedentes.

Após a vivência em Canudos, Euclides da Cunha convenceu-se de que o movimento de Canudos não defendia a volta da Monarquia, nem tampouco abolia os ideais republicanos, ao contrário, lutava pelo sertanejo e pela sua sobrevivência.

Euclides da Cunha, com propriedade e com verdade, nos conduz pela narrativa sem propriamente nos conduzir, deixando que as descobertas e o sofrimento sejam de nossa responsabilidade.

Certamente, não há dúvidas da grandiosidade da obra, nem de outras tantas possibilidades de análises a partir da(s) leitura(s). Por essa razão, ressaltamos e sugerimos que experenciem, em algum momento, Euclides e Os Sertões. A linguagem utilizada na obra condiz com o vasto conhecimento do autor, um bocado de sua irreverência e um dizer crítico sobre a sociedade brasileira da época, quase uma mescla de ciência e arte, prosa e poesia. 